\title{
How to Cope with Volatile Commodity Export Prices: Four Proposals
}

\author{
Jeffrey Frankel \\ CID Faculty Working Paper No. 335
}

July 2017

(c) Copyright 2017 Frankel, Jeffrey; and the President and Fellows of Harvard College

\section{Working Papers Center for International Development at Harvard University}


July $31,2017+$ Abstract

\title{
"How to Cope with Volatile Commodity Export Prices: Four Proposals"
}

\section{Jeffrey Frankel, Harvard Kennedy School}

Keynote Address, High Level Seminar, Natural Resources, Finance and Growth, sponsored by the Bank of Algeria, Algiers, May 28-29, 2016. Forthcoming in an e-book edited by Rabah Arezki and Raouf Boucekkine. The author would like to thank participants at the Bank of Algeria conference; the annual research conference of the Bank of Chile, Santiago, Oct. 23, 2014; a seminar of the OCP Policy Center, Casablanca, Morocco, June 3, 2016; the annual meeting of the Agricultural and Applied Economics Association, Boston, August 1, 2016; and a conference at the Inter-American Development Bank, April 18, 2017.

\begin{abstract}
Countries that specialize in commodities have in recent years been hit by high volatility in world prices for their exports. This paper suggests four ways that commodity-exporters can make themselves less vulnerable. (1) Option contracts can be used to hedge against short-term declines in the commodity price without giving up the upside, as Mexico has shown. (2) Commodity-linked bonds can hedge longer-term risk, and often have a natural ultimate counter-party in multinational corporations that depend on the commodity as an input. (3) The well-documented pro-cyclicality of fiscal policy among commodity exporters can be reduced by insulating official forecasters against an optimism bias, as Chile has shown. (4) Monetary policy can be made automatically more counter-cyclical, judged by the criterion of currency appreciation in reaction to positive terms-of-trade shocks, under either of two regimes: peggers can add the export commodity to a currency basket (CCB, for "Currency-plusCommodity Basket") and others can target Nominal Income instead of the CPI.
\end{abstract}

AEA subject codes: $E, F, G, O$.

Keywords: agriculture, commodities, currency basket, fiscal, hedging, indexed bonds, minerals, monetary, oil. 


\section{"How to Cope with Volatile Commodity Export Prices: Four Proposals"}

\section{Introduction}

Countries where exports are relatively concentrated in oil, gas, minerals and agricultural commodities experience terms of trade that are highly volatile. This volatility is one of the possible explanations for the famous Natural Resource Curse. ${ }^{1}$

The aim in this keynote address is to offer four policy proposals to help countries manage commodity volatility and thereby help make sure that commodity wealth is a blessing rather than a curse. Two of the ideas fall in the area of microeconomic policy: specific financial contracts structured so as to hedge risk. Two of the ideas fall in the area of macroeconomic policy institutions: ways to make fiscal and monetary policy counter-cyclical rather than procyclical.

It is always hard to make policy proposals that are convincing and at the same time are original. I will try to strike a balance between being convincing and being original. Of the four ideas, two are tried and tested. Two have not been tried much. The question then becomes: why not?

Let us first pause to ask: Don't commodity-exporters already use financial markets to smooth trade fluctuations? If international financial markets worked well, countries facing temporary adverse trade shocks could borrow to finance current account deficits, and vice versa. But they don't work that well. Capital flows to developing countries tend, if anything, to be pro-cyclical. ${ }^{2}$ The appropriate theory usually builds on the assumption that borrowing requires collateral, in the form of commodity export proceeds. The important point for policymakers is that some careful thought is required to design institutions that can protect against the volatility.

Many other policies and institutions for dealing with commodity volatility have been proposed and tried in various countries, some successful, some much less so. Many of the ideas that tend to work poorly can be described as seeking to suppress price volatility rather than manage it. I see them as akin to King Canute commanding the tide not to come in. I am thinking, for example, of price controls, commodity marketing boards, and controls on exports.

\footnotetext{
${ }^{1}$ Brueckner and Carneiro (2016), Blattman, Hwang, and Williamson (2007), Hausmann and Rigobon (2003), Mendoza (1997) and Poelhekke and van der Ploeg (2007). Terms of trade volatility hurts growth in the presence of investment irreversibilities and credit constraints (Aghion, Angeletos, Banerjee \& Manova, 2010). Frankel (2012a) surveys the Natural Resource Curse.

${ }^{2}$ E.g., Kaminsky, Reinhart and Végh \{2005).
} 
Better to accept fluctuations in demand and supply as a fact of life, and to devise policies and institutions to equip the economy to cope with them.

\section{Idea for financial hedging of short-term risk: Options}

The general theoretical case for hedging is clear. Hedging allows for efficient sharing of risk. $^{3}$

Of my two suggestions for ways to hedge risk, one having to do with derivatives has been tried and proven successful in protecting against short-term declines in the world price of the export commodity. I have in mind the options market. Mexico annually buys contracts for put options on a large scale to protect itself against a decline in the dollar price of oil. ${ }^{4}$ This strategy proved especially useful when global commodity prices fell abruptly in 2009 and 201415.

Why not use the futures or forward market? Ghana has apparently tried this for cocoa, with some success. ${ }^{5}$ But the futures strategy has a major potential drawback, which might be described as an incentive compatibility problem. The minister who sells the commodity forward is likely to get meager credit if the dollar price of the commodity subsequently goes down, but lots of blame if the price goes up. Better to use options to eliminate the downside risk while keeping the upside potential, although of course one must pay a price for the latter.

A possible limitation in practice for both futures and options contracts is that they are not always readily available for some commodities, particularly at the long-term horizons needed to hedge development of new oil or mineral resources. This observation leads to proposal number two.

\section{Idea for financial hedging of long-term risk: Linking debt to the commodity price}

For those countries that borrow, e.g., a West African country that is developing new deposits of iron ore or offshore oil, I propose linking the terms of the loan, not to dollars nor to the local currency, but to the price of the commodity itself. ${ }^{6}$ Then debt service obligations are

\footnotetext{
${ }^{3}$ E.g., Borensztein, Jeanne and Sandri (2013).

${ }^{4}$ Duclaud and García (2011).

${ }^{5}$ IMF SPRD and World Bank PREM (2011, p.47).I

${ }^{6}$ Frankel, "Barrels, Bushels and Bonds: How Commodity Exporters Can Hedge Volatility," Project Syndicate, October 2011.
} 
matched to revenues: they automatically rise and fall with the value of the exports. When debt crises hit Indonesia, Russia and Ecuador in 1998, or Ghana, Ecuador, Nigeria and Venezuela in 2015 , one reason was that low dollar prices of their oil exports had driven up their debt service ratios. This would not have happened if their debts had been indexed to the oil price.

The indexation idea has been around for a long time, but has very seldom been put into practice. Why not? Potential issuers worry that there is not enough demand for such commodity bonds. Who would want to take the other side of the trade, they ask? There is a good answer to the question who the ultimate potential customers are. Airlines and power utility companies have reason to go long in oil, steelmakers have reason to go long in iron ore, chocolate makers to go long in cocoa, etc. ${ }^{7}$

It must be that bonds denominated in a particular kind of oil and carrying the credit risk of a particular country are too specialized a niche to generate the necessary liquidity to make a viable market. A power company or airline wants to go long in oil, not long in exposure to Azerbaijan, Nigeria or Ecuador, whose credit risk it is not equipped to evaluate. But then the World Bank might be able to make the market: It would lend to interested oil-producing countries - which is its job -- in terms of oil in place of lending to them in dollars. It would then offset its collective exposure to oil market conditions by selling to investors a World Bank bond denominated in a standard oil price index. Similarly with iron ore, cocoa, gold, coffee, and other commodities. Certain major private banks might also be able to play this role.

\section{Institutions to overcome pro-cyclical fiscal policy in commodity-exporting countries.}

The third area is fiscal policy. Government spending has historically been notoriously pro-cyclical in commodity-exporting countries. Governments have tended to increase spending during the boom and have then been forced to cut back when commodity prices go back down. Many authors have documented this historical pro-cyclicality. ${ }^{8}$ An important cause of procyclical spending is that government receipts from taxes or royalties rise in booms, and the government cannot resist the temptation or political pressure to increase spending

\footnotetext{
${ }^{7}$ Logically, commodity bonds should be "an easier sell" than GDP-linked bonds, which have received more attention (e.g., Borensztein and Mauro, 2004). The first reason is that they have natural customers, as noted. The second reason is that the commodity price index is not subsequently revised and is less liable to government manipulation than are GDP statistics.

8 Cuddington (1989), Gavin and Perotti (1997), Tornell and Lane (1999), Kaminsky, Reinhart, and Vegh (2004), Talvi and Végh (2005), Alesina, Campante and Tabellini (2008), Mendoza and Oviedo (2006), Ilzetski and Vegh (2008), Medas and Zakharova (2009), Arezki, Hamilton and Kazimov (2011), Erbil (2011), and Avellan \& Vuletin (2015)..
} 
proportionately, or more than proportionately, as if the boom will last forever. Two large budget items that account for much of the increased spending from oil booms are big construction projects and the government wage bill. ${ }^{9}$

It is not enough to observe that policy-makers should follow wiser policies. What is wanted are institutions that make it more likely that fiscal policy will be counter-cyclical, or at least less pro-cyclical, even when carried out by officials who suffer from the common political and human frailties.

Some commodity-exporting developing countries managed after 2000 to overcome this historical pattern of pro-cyclicality. They achieved fiscal counter-cyclicality: taking advantage of the 2002-08 expansion to strengthen their budget balances, which then gave them the "fiscal space" to ease up when the global recession hit in 2009. Which countries managed this achievement? Generally those with "good institutions" such as the rule of law. ${ }^{10}$

What institutional innovations, more specifically, can a country adopt to fight fiscal procyclicality? The conventional answer is budget rules, for example legally entrenched ceilings on budget deficits. But such rules alone won't do the job, as the failures of Europe's Stability and Growth Pact has amply demonstrated. To begin with, fixed ceilings on budget deficits operate pro-cyclically: when the economy is hit by a recession and so the budget is hit by a loss in tax revenue, a budget balance rule will force the government to cut spending or raise tax rates. Phrasing the target in cyclically adjusted terms helps solves that problem in theory. But most such rules are violated in practice, even more so for EM countries than for advanced countries. One major reason is overly optimistic forecasts by official agencies. ${ }^{11}$

A study of Chile's successful fiscal institutions ${ }^{12}$ concluded that the key feature was not by itself the adoption of cyclically adjusted budget balance. Others have tried this and failed. It was, rather, the delegation to independent committees of the responsibility to estimate the long-run trends in the copper price and GDP. This delegation avoided the systematic overoptimism that plagues official forecasts in most other countries. It could be a useful model for others to emulate.

\footnotetext{
${ }^{9}$ Gelb (1986) and Medas and Zakharova (2009), respectively.

${ }^{10}$ Céspedes and Velasco (2014) and Frankel, Végh and Vuletin (2013).

${ }^{11}$ Frankel and Schreger (2013).

${ }^{12}$ Frankel (2013). Summarized in "Chile's Countercyclical Triumph," Foreign Policy, June 2012.
} 


\section{Ideas to overcome pro-cyclical monetary policy in commodity-exporting countries}

The Fed and some other of the most important central banks may have given up, at least for the time being, on the attempt to communicate monetary policy intentions in terms of a single variable, even via forward guidance, let alone via an explicit target. The presumption, however, is still in favor of transparency and simple clear communication. Many still feel the need to announce a specific target or anchor. Most developing countries, in particular, need the reinforcement to credibility. ${ }^{13}$ Monetary policy-makers in emerging market and developing countries often have more need for credibility than those in advanced countries due to highinflation histories, absence of credible institutions, or political pressure to monetize big budget deficits. But announcing a target that one can expect often to miss does little to enhance credibility.

Commodity-exporting countries have bigger terms of trade shocks than industrialized countries. As has long been understood, terms of trade volatility makes a country less suited to a fixed exchange rate and more suited toward some form of floating so that the exchange rate can accommodate terms of trade shocks.

One good criterion for judging whether monetary policy in a commodity-exporting country is counter-cyclical is whether the currency is allowed to appreciate in the face of a positive terms-of-trade shock and depreciate in the face of a negative terms-of-trade shock. By this criterion, a fixed exchange rate is acyclical, by definition. By other criteria, a currency peg can actually be pro-cyclical: Commodity booms are associated with money inflows, rapid credit expansion, an overheated real economy, inflation in non-traded goods and services, and bubbles in real estate and other assets. Conversely, commodity busts are associated with balance of payments deficits, loss of reserves, credit shortage, recession, and currency or financial crises.

Flexible exchange rates allow accommodation of trade shocks and therefore a countercyclical monetary policy. Under free floating, when the global price of the export commodity rises, threatening overheating, the currency automatically appreciates to mitigate the problem. When the global price of the export commodity falls, threatening external balance difficulties and recession, the currency automatically depreciates to mitigate those problems.

Examples of "commodity currency" countries include Australia, Canada, Chile, New Zealand and South Africa, among others. ${ }^{14}$ Empirically, floating delivers a high correlation

\footnotetext{
${ }^{13}$ Fraga, Goldfajn, and Minella (2003).

${ }^{14}$ Cashin, Céspedes, and Sahay (2004); Chen and Rogoff (2003); Frankel (2007). .
} 
between the exogenous price of the export commodity and the real effective exchange rate, thus accommodating terms of trade shocks, while fixing does not. A variety of empirical studies confirm that floating works better for countries exposed to volatility in the world prices of their export commodities: Broda (2004), Edwards and Levy-Yeyati (2005), Rafiq (2011), Céspedes and Velasco (2012) and Berg, Goncalves and Portillo (2016).

Of course the advantages of fixing are still likely to dominate for very small very open economies (or for low-income countries that lack developed financial markets). Examples among oil exporters include Bahrain, Brunei, Cameroon, and Trinidad.

For middle-sized middle-income commodity-exporting countries, if the exchange rate is not to be the anchor, what is? The popular choice since the 1990s has been Inflation Targeting (IT), meaning the announcement of a targeting for the CPI in some form. IT comes in variations. Choices include targeting the level of the CPI versus the rate of change, headline CPI versus core, and forecasted inflation versus actual.

One point is not widely enough considered: Regardless which variation, the CPI is a bad choice for targeted variable with respect to terms of trade shocks. Assume a country that exports oil and imports food. If interpreted literally, a CPI target prevents the central bank from responding to a fall in the dollar price of oil with easy enough money to depreciate the currency (otherwise the domestic price of food will rise, violating the CPI target); and it requires the central bank to respond to a rise in the dollar price of imported food by tightening enough to appreciate the currency (for the same reason). This is backwards. It exacerbates terms-oftrade shocks rather than accommodating them. A short-term CPI target produces pro-cyclical monetary policy rather than counter-cyclical. It is like the currency peg in this regard, but more so.

If the authorities are going to target inflation, the price index should be one that leaves the import commodity out of the basket, but includes the price of the export commodity: something output-based, rather than designed to reflect the consumption basket. If the Bank of Algeria were to target the GDP deflator, it would automatically respond to declines in the world price of oil with monetary policy easy enough to depreciate the dinar, which is what one wants, and not when the price of the import commodity falls which is what a CPI target does. ${ }^{15}$ Unfortunately, nobody has tried out the proposal to target the GDP deflator.

An alternative, especially for countries like Kuwait that currently target a basket of major currencies such as the dollar and euro, is to add the export commodity to the basket. If the Kuwaiti dinar were pegged to a basket that gave one-third weight to the dollar, one-third to

${ }^{15}$ Frankel (2011, 2012b). 
the euro, and one third to oil, the value of the currency would again automatically move up and down with the value of a barrel of oil. Among Gulf countries, swings in external balance and in internal balance during 2001-16, are attributable to the inability of their exchange rates to adjust to the ups and downs in oil prices in a way that the proposal for a Currency-plus-Commodity Basket (CCB) would deliver automatically. ${ }^{16}$ The argument in favor of CCB is that, for a commodity-exporting developing country, it delivers the best of floating - automatic accommodation of trade shocks - together with the best of fixed rates - a stable and transparent anchor. This proposal, too, has yet to be tried.

A more familiar recommendation is to target nominal GDP. ${ }^{17}$ It has the same advantages as targeting the nominal GDP deflator (accommodating shocks to the terms of trade better than a CPI target), and has other advantages as well: It also beats CPI-targeting in case of supply shocks.

I am not alone in proposing NGDP targeting; many other economists have done so. The other supporters have almost always been thinking of major central banks like the Federal Reserve or the Bank of England. In the 1980s NGDP targeting was proposed by Meade (1978) and Tobin (1980) and supported by many others. The point of announcing an explicit target at that time was to get expectations of inflation down. In recent years the proposal has been revived (e.g., by Woodford, 2012, plus a school that calls itself Market Monetarists). The point nowadays has been to get expectations of inflation up. Either way, the argument in favor of phrasing the monetary stance in terms of NGDP is that this formulation is robust with respect to supply shocks

One can show that if the ultimate objective is to achieve price stability and output stability, as represented by a quadratic loss function, then a NGDP target will give a better outcome in the presence of shocks than an inflation target unless the supply curve is very steep or the loss function puts extraordinarily high weight on stabilizing the CPI.

Under certain simplifying assumptions, the necessary condition for Nominal GDP Targeting (NGDPT) to dominate Inflation Targeting (IT) is:

$$
a<(2+b) b
$$

where $\boldsymbol{a} \equiv$ the weight on the price stability objective in the loss function, and $\boldsymbol{b} \equiv$ elasticity of output with respect to unexpected inflation (i.e., inverse slope of Aggregate Supply curve).

The difference in welfare is especially large if supply shocks are especially large. There is good reason to think that supply shocks, like terms of trade shocks, are larger for commodity producers and other developing countries, due to more strikes and social instability, greater

\footnotetext{
${ }^{16}$ Frankel $(2008,2017)$, summarized in Policy Brief No. 26, June 2017 (Economic Research Forum, Cairo).

${ }^{17}$ See Frankel (2014) and Bhandari and Frankel (2017), summarized in "Nominal GDP Targeting for Developing Countries," VoxEU, Aug. 2014.
} 
vulnerability to severe weather events such as droughts and windstorms and other natural disasters such as earthquakes, and bigger productivity shocks. ${ }^{18}$

Does the inequality condition hold? It does if the Aggregate Supply (AS) relationship is flat, as compared to the slope of the loss function lines. To simplify even further, consider two examples.

- Example 1: The condition holds if $\mathbf{b}>\boldsymbol{a}$.

- Example 2: It also holds if $\boldsymbol{a}=1$ (as in the original Taylor rule) and the AS slope $1 / \boldsymbol{b}<(1+\sqrt{2}$ ) $=2.414$.

So NGDP targeting dominates unless Aggregate Supply is very steep (relative to the weight on price stability). I have estimated the AS slope for a few middle-size middle-income countries where I could think of plausible instruments for Aggregate Supply shocks and Aggregate Demand shocks. A good one is Kazakhstan, over the period 1993-2012. (The exogenous supply shocks are oil price fluctuations. Exogenous demand shocks are changes in income of major trading partners and military spending.) The estimated AS slope is 1.66; it is statistically less than 2.41 . The implication is that the condition required for NGDPT to dominate IT apparently holds.

I conclude that middle-size middle-income commodity-exporting countries that currently favor targeting the CPI should consider using nominal GDP as their target instead. Commodity-exporting countries that currently peg their exchange rates to one or more major currencies should consider adding the export commodity to the basket to which they peg. In both cases the aim is to accommodate the trade shocks to which commodity-exporters are so often vulnerable.

\footnotetext{
${ }^{18}$ During a boom, the country does not know in real time whether rapid productivity growth is permanent -- it is the next Asian Tiger -- or temporary -- the result of a transitory fluctuation. (Aguiar and Gopinath, 2007.) Because exogenous productivity shocks are hard to measure, extreme weather events and commodity price fluctuations are more useful as instrumental variables.
} 


\section{References}

Aghion, Philippe, George-Marios Angeletos, Abhijit Banerjee, and Kalina Manova, 2010, "Volatility and Growth: Credit Constraints and the Composition of Investment," Journal of Monetary Economics 57, no. 3: $246-265$.

Aguiar, Mark, and Gita Gopinath, 2007, "Emerging Market Business Cycles: The Cycle is the Trend," Journal of Political Economy 115, 1, February.

Alesina, Alberto, Filipe Campante, and Guido Tabellini, 2008, "Why is Fiscal Policy Often Procyclical?" Journal of the European Economic Association, 6, no. 5, September, 1006-1036.

Arezki, Rabah, Kirk Hamilton and Kazim Kazimov, 2011, "Resource Windfalls, Macroeconomic Stability and Growth: The Role of Political Institutions," (International Monetary Fund: Washington DC), May.

Avellan, Leopoldo, and Guillermo Vuletin. "Fiscal Procyclicality and output forecast errors." Journal of International Money and Finance 55 (2015): 193-204.

Berg, Andrew, Carlos Goncalves and Rafael Portillo, 2016, “Another disconnect puzzle: should floaters fix and fixers float?" International Monetary Fund.

Bhandari, Pranjul, and Frankel, Jeffrey, 2017, “Nominal GDP Targeting for Developing Countries," Research in Economics (Elsevier), September. NBER WP 20898.

Blattman, Christopher, Jason Hwang, and Jeffrey Williamson, 2007, "Winners and Losers in the Commodity Lottery: The Impact of Terms of Trade Growth and Volatility in the Periphery 1870-1939," Journal of Development Economics (Elsevier), vol. 82, no.1, pages 156-179, January. NBER WP 10600.

Borensztein, Eduardo, Olivier Jeanne and Damiano Sandri, 2013, "Macro-hedging for commodity exporters," Journal of Development Economics.

Borensztein, Eduardo, and Paolo Mauro, 2004, "The case for GDP-indexed bonds." Economic Policy 19.38: $166-216$.

Broda, Christian, 2004, "Terms of Trade and Exchange Rate Regimes in Developing Countries," Journal of International Economics, 63(1), pp. 31-58.

Brueckner, Markkus, and Francisco Carneiro, 2016, "Terms of Trade Volatility, Government Spending Cyclicality, and Economic Growth," CAMA Working Paper 36/2016, Australia National University, June.

Cashin, Paul, Luis F. Céspedes, and Ratna Sahay, 2004,. "Commodity Currencies and the Real Exchange Rate." Journal of Development Economics 75, no.1: 239-268.

Céspedes, Luis Felipe, and Andrés Velasco, 2012,"Macroeconomic Performance During Commodity Price Booms and Busts." IMF Economic Review 60, no.4: 570-599.

Céspedes, Luis Felipe, and Andrés Velasco, 2014, "Was this Time Different? Fiscal Policy in Commodity Republics," Journal of Development Economics (Elsevier), vol. 106 (C), pp. 92-106.

Chen, Yu-chin, and Kenneth Rogoff, 2003, "Commodity Currencies," Journal of International Economics 60, no.1: 133-160. 
Cuddington, John, 1989, "Commodity Export Booms in Developing Countries," World Bank Research Observer 4, 143-165.

Duclaud, Javier, and Gerardo García, 2011, “Mexico’s Oil Price Hedging Program” (International Monetary Fund).

Edwards, Sebastian, and Eduardo Levy Yeyati, 2005, "Flexible Exchange Rates as Shock Absorbers," European Economic Review, Vol. 49, Issue 8, November, pp. 2079-05.

Erbil, Nese, 2011, “Is Fiscal Policy Procyclical in Developing Oil-producing Countries?” IMF Working Papers (International Monetary Fund).

Fraga, Armino, Ilan Goldfajn, and André Minella, 2003, “Inflation Targeting in Emerging Market Economies," NBER Macro Annual 2003, Kenneth Rogoff and Mark Gertler, editors (MIT Press: Cambridge).

Frankel, Jeffrey, 2007, “On the Rand: Determinants of the South African Exchange Rate," South African Journal of Economics, vol.75, no.3, September, 425-441.

Frankel, Jeffrey, 2008, "UAE \& Other Gulf Countries Urged to Switch Currency Peg from the Dollar to a Basket That Includes Oil," Vox.EU, July 9.

Frankel, Jeffrey, 2011, “A Comparison of Product Price Targeting and Other Monetary Anchor Options, for Commodity-Exporters in Latin America," Economia, vol. 12, no. 1: 1-57. NBER WP 16362.

Frankel, Jeffrey, 2012a, "The Natural Resource Curse: A Survey of Diagnoses and Some Prescriptions," in Commodity Price Volatility and Inclusive Growth in Low-Income Countries, edited by Rabah Arezki, Catherine Patillo, Marc Quintyn and Min Zhu (International Monetary Fund: Washington DC).

Frankel, Jeffrey, 2012b, "Product Price Targeting -- A New Improved Way of Inflation Targeting," in MAS Monetary Review Vol. XI, issue 1, April (Monetary Authority of Singapore), pp.2-5.

Frankel, Jeffrey, 2013, “A Solution to Fiscal Procyclicality: The Structural Budget Institutions Pioneered by Chile," in Fiscal Policy and Macroeconomic Performance, Luis Felipe Céspedes and Jordi Galí, eds., Series on Central Banking Analysis, and Economic Policies, vol.17. Also in Spanish translation, Journal Economía Chilena, vol.14, no.2, August 2011 (Central Bank of Chile), pp.39-78.

Frankel, Jeffrey, 2014, Nominal GDP Targeting for Middle-Income Countries," Central Bank Review, vol.14, no.3, September (Central Bank of the Republic of Turkey), pp.1-14. HKS RWP 14-033.

Frankel, Jeffrey, 2017, “The Currency-Plus-Commodity Basket: A Proposal for Exchange Rates in Oil-Exporting Countries to Accommodate Trade Shocks Automatically," forthcoming in: Macroeconomic Institutions and Management in Resource-Rich Arab Economies, Hodi Selim, ed., (Oxford: Oxford University Press). CID WP no 333.

Frankel, Jeffrey, and Jesse Schreger, 2013, "Over-optimistic Official Forecasts in the Eurozone and Fiscal Rules," Review of World Economy, vol. 149, no. 2, pp.247-272; NBER WP 18283.

Frankel, Jeffrey, Carlos Végh and Guillermo Vuletin, 2013, "On Graduation from Fiscal Procyclicality," in Journal of Development Economics, 100, no.1, Jan., pp. 32-47; NBER WP 17619; summarized in VoxEU. 
Gavin, Michael and Roberto Perotti, 1997, "Fiscal Policy in Latin America," NBER Macroeconomics Annual, Vol. 12, pp. 11-61.

Gelb, Alan, 1986, “Adjustment to Windfall Gains: A Comparative Analysis of Oil-Exporting Countries," in Natural Resources and the Macroeconomy, J.Peter Neary and van Sweder Wijnbergen, eds. (MIT Press: Cambridge), 54-93.

Hausmann, Ricardo, and Roberto Rigobon, 2003, “An Alternative Interpretation of the 'Resource Curse': Theory and Policy Implications," in Fiscal Policy Formulation and Implementation in Oil-Producing Countries, edited by Jeffrey Davis (International Monetary Fund: Washington, DC), pp;.12-44.

Ilzetski, Ethan, and Carlos Vegh, 2008, “Procyclical Fiscal Policy in Developing Countries: Truth or Fiction?" NBER WP no. 14191.

IMF SPRD \& World Bank PREM, 2011, “Managing Volatility in Low-Income Countries: The Role and Potential for Contingent Financial Instruments," approved by Reza Moghadam and Otaviano Canuto, Oct..

Kaminsky, Graciela, Carmen Reinhart, and Carlos Vegh, 2005, "When It Rains, It Pours: Procyclical Capital Flows and Macroeconomic Policies," NBER Macroeconomics Annual 2004, Vol. 19, pages 11-82.

Meade, James, 1978, “The Meaning of Internal Balance,” The Economic Journal, 88:423-435.

Medas, Paolo, and Daria Zakharova, 2009, “Primer on Fiscal Analysis in Oil-Producing Countries," IMF working paper 56, March.

Mendoza, Enrique G., 1997, "Terms-of-trade Uncertainty and Economic Growth," Journal of Development Economics 54.2: 323-356.

Mendoza, Enrique, and P. Marcelo Oviedo, "Fiscal Policy and Macroeconomic Uncertainty in Developing Countries: The Tale of the Tormented Insurer," NBER Working Paper No. 12586, October.

Poelhekke, Steven, and, Frederick van der Ploeg, 2007, "Volatility, Financial Development and the Natural Resource Curse," CEPR DP6513, October.

Rafiq, M. Sohrab, 2011, "Sources of Economic Fluctuations in Oil-exporting Economies: Implications for Choice of Exchange Rate Regimes," International Journal of Finance \& Economics 16, no.1: 70-91.

Talvi, Ernesto, and Carlos Vegh, 2005, "Tax Base Variability and Procyclicality of Fiscal Policy," Journal of Development Economics 78, no. 1, 156-190.

Tobin, James,1980, “Stabilization Policy Ten Years After,” Brookings Papers on Economic Activity 1: 19-72.

Tornell, Aaron, and Philip Lane, 1999, “The Voracity Effect," American Economic Review 89, no. 1, March: $22-46$.

Woodford, Michael, 2012, "Methods of Policy Accommodation at the Interest-Rate Lower Bound," The Changing Policy Landscape: 2012 Jackson Hole Symposium (Federal Reserve Bank of Kansas City). 